\title{
Antiretroviral Therapy Perceived Efficacy and Risky Sexual Behaviors: Evidence from Mozambique
}

\author{
DAMIEN DE WALQUE \\ World Bank
}

HAROUNAN KAZIANGA

Oklahoma State University

MEAD OVER

Center for Global Development

\section{Introduction}

Access to HIV/AIDS treatment has likely transformed the perception of AIDS from a death sentence to a manageable chronic condition (Lakdawalla, Sood, and Goldman 2006), no different from any other chronic disease. Expanding access to treatments has become one of the key strategies of the international community to confront AIDS. For instance, universal access to treatment is one of the stated goals of the joint United Nations programs on HIV/AIDS (UNAIDS). The call for scaling-up treatment, especially in low income countries, has generated a debate on how treatment may affect the dynamics of the disease.

Increased access to treatment can influence the spread of the disease in many ways. On the one hand, access to treatment may provide incentives for HIV testing by reducing the costs of finding one's sero-positivity. Once people find that they are sero-negative, they would have more incentives to adopt safer

We are grateful for funding from the Dutch Government via the Bank Netherlands Partnership Program (BNPP), Irish AID, and the Hewlett Foundation for grant support through Trust Fund TF070424 given to the World Bank. Mead Over acknowledges the support of a grant to the Center for Global Development from the Bill and Melinda Gates Foundation. We are grateful to Humberto Cossa, Jean-Jacques de Saint-Antoine, Elizabeth Lule, and Albertus Voetberg for supporting this research project. We thank Adam Wagstaff, seminar participants at the World Bank, and participants at the symposium and Festschrift in Paul Schultz's honor, two anonymous referees, and the editor for very useful comments. We thank Rita Costa, Anjali Oza, and Julia Vaillant for outstanding research assistance. The findings, interpretations, and conclusions expressed in this paper are entirely ours. They do not necessarily represent the view of the World Bank, its executive directors, or the countries they represent. Contact the corresponding author, Harounan Kazianga, at harounan .kazianga@okstate.edu.

(c) 2012 by The University of Chicago. All rights reserved. 0013-0079/2012/6101-0005\$10.00 
sexual behaviors (e.g., Mechoulan 2007). ${ }^{1}$ Moreover, HIV positive individuals may become less infectious if treatment is initiated early enough (e.g., Cohen et al. 2011). On the other hand, decreased fear of contracting HIV, resulting from access to treatment, may increase risky behavior, reduce sero-sorting, and increase the mixing between higher- and lower-risk groups in the population. Moreover, as survival increases, the incidence of exposure to partners with HIV infection may increase (Hammer et al. 2006). There are anecdotal reports which suggest that, in some parts of sub-Saharan Africa, increasing beliefs that AIDS can be treated by ART (antiretroviral treatment) or cured by ART have caused a decline of safe sexual practices, which in turn have led to an increase in sexually transmitted infections (e.g., Green and Ruark 2011). Such disinhibition behaviors, if confirmed, would imply that scaling-up antiretroviral treatment would not be as effective if treatment expenditures crowd out behavioral prevention programs (Over et al. 2006, 2007).

In this paper, we present an empirical analysis of the perceived efficacy of ART on sexual behaviors. Our measures of risky sexual behaviors consist of individuals' reports of (a) unprotected sex with non-coresiding partners in the last 12 months (risky sex), (b) any casual sex (sexual intercourse with noncoresiding partners with or without a condom) and (c) abstinence. We chose these three measures of sexual behaviors to reflect the so-called $A, B$ and $C$ (abstinence, be faithful, or condom) that have been promoted in HIV/AIDS prevention programs and are believed to have contributed to controlling the spread of the disease in some parts of sub-Saharan Africa (e.g., Singh, Darroch, and Bankole 2004). Our measures of ART perceived efficacy consist of "the belief that ART can cure AIDS" and "the belief that ART can treat AIDS, but cannot cure it." We combine these two measures into a single indicator of how easily respondents believe AIDS can be managed. The study covers a period when access to ARTwas increasing in Mozambique, due in part to the Treatment Acceleration Program (TAP). ${ }^{2}$ The TAP was a World Bank project that aimed at piloting strategies for strengthening capacity to scale up comprehensive HIV/ AIDS programs in Africa (ACTAfrica and Global HIV Program 2007).

We make four main contributions to the literature on individual risk offsetting behaviors. First, the survey instrument asked individuals about the perceived efficacy of ART. We show how these ART perceived efficacy variables correlate strongly with self-reported sexual behaviors. Second, through a matched survey of health facilities we are able to correlate local ART experience with the ART perceived efficacy variables. Third, our paper is unique in the

\footnotetext{
${ }^{1}$ Note that increased demand for testing could also lead to early detection, which would make treatment more effective.

${ }^{2}$ The TAP was also piloted in Burkina Faso and in Ghana.
} 
attempt to exploit the panel structure of the data to control for time-invariant unobserved individual characteristics and time-varying community level unobserved characteristics that may otherwise influence both sexual behavior and ART perceived efficacy. Fourth, our sample covers three categories of respondents: HIV positive individuals, individuals who live in a household where there is at least one identified HIV positive person, and individuals who live in comparison households, that is, households where there is no identified HIV positive person. This feature of our sample allows us to directly test how response to ART perceived efficacy varies between HIV positive individuals and the general population.

Mozambique offers an interesting setting for exploring potential disinhibition behaviors. Mozambique ranks among the 10 countries most affected by the HIV/AIDS epidemic. The prevalence was estimated to be between $14 \%$ and $17 \%$ in 2009 and has remained that high since at least 2002 (UNGASS 2010). The national effort to confront the disease includes increased access to ART. The number of patients under ART drugs has increased from 3,314 in 2003 to 170,198 in 2009 (UNGASS 2010). Treatment coverage, however, remains low. In 2009, it was estimated that $42 \%$ of adults and $19 \%$ of children in need of ART were receiving treatment (UNGASS 2010). ${ }^{3}$ Mozambique illustrates the ongoing debate on how to optimally allocate limited resources between treatment and prevention in sub-Saharan Africa (e.g., Marseille, Hofmann, and Kahn 2002), if the ultimate goal is to contain the disease. In this context, as stressed by Schultz (2004), robust estimates of the magnitude of disinhibition behaviors are critical for any informed decision making, since such estimates would allow accounting for externalities (whether negative or positive) associated with increased access to ART.

This paper is related to a strand of literature that focuses on disinhibition (or risk compensation) behaviors. ${ }^{4}$ The main proposition of this literature is that people may alter their behavior in response to perceived changes in risk. In the specific case of HIV/AIDS and increased access to ART, the concern is that decrease in the perceived risk and the costs of contracting HIV associated with increased access to ART may lead to an increase of risky sexual behaviors (e.g., Eaton and Kalichman 2007). Such disinhibition behaviors, if large enough, may (at least partially) offset the benefits of scaling-up access to ART. This conjecture is supported by several studies in the United States and Europe that have identified an upward trend in risky sexual behaviors since the introduction

\footnotetext{
${ }^{3}$ See Arndt (2006) for a simulation analysis of the long-run impact of HIV/AIDS on economic growth in Mozambique and, in particular, on human capital accumulation.

${ }_{4}^{4}$ See Peltzman (1975) for an early study on the introduction of mandatory car seat belts in the United States.
} 


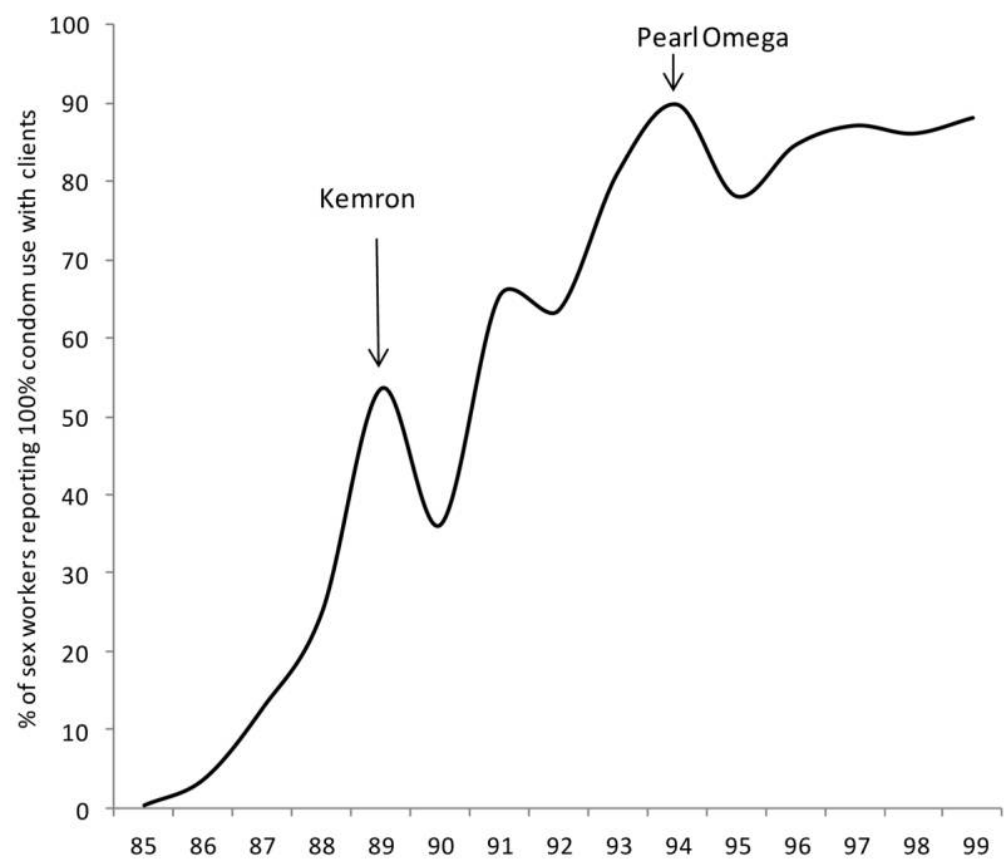

Figure 1. Percent condom use in a cohort of sex workers declined after the local announcement of each of two fraudulent "cures" for AIDS: Nairobi, 1985-99. Source: Jha et al. 2001.

of ART in 1996 (e.g., Gremy and Beltzer 2004; Lakdawalla et al. 2006). More specifically, an association has been identified between decreased concern about HIV due to ART availability and unprotected sex, and in particular among men who have sex with men (e.g., Kalichman 1998; Dukers et al. 2001; Lakdawalla et al. 2006; Mechoulan 2007).

Investigations of disinhibition behaviors associated with increased access to ART in sub-Saharan Africa are, however, limited. One of the earliest studies looked at change in the use of condoms by sex workers in Nairobi (Kenya) when fraudulent AIDS cures (Kemron and Pearl Omega) received wide coverage in the press ( Jha et al. 2001). The findings are summarized in figure 1 . These data provide at least some suggestive evidence that condom use by sex workers decreased when the fraudulent cures for AIDS were announced. However, after a year or more the sampled cohort resumed condom use, perhaps because they had learned that the proposed "cures" did not work. Such a pattern is consistent with disinhibition behaviors, although the result may not be generalizable to the general population since it uses a selected segment of the population. Cohen et al. (2009) is one of the few studies that use population-based surveys to investigate risk compensation behavior in a subSaharan African context. The authors found that in Kisumu (Kenya), ART- 
related risk compensation ${ }^{5}$ and the belief that ART cures HIV were associated with an increased HIV sero-prevalence in men but not women.

We differ from Cohen et al. (2009) in two ways. First, we focus on selfreported sexual behavior instead of HIV sero-prevalence. People respond to increased access to ART by changing their sexual behaviors, and these changes in sexual behaviors could lead to change in sero-prevalence. Second, the panel structure of our data allows us to control for unobserved individual characteristics that can influence both sexual behavior (and HIV sero-prevalence) and perceptions on ART and, thus, lead to biased estimates of disinhibition behaviors. This source of bias remains a concern with the results of Cohen et al. (2009) despite the careful design of their field survey. ${ }^{6}$

We find a strong and positive association between the perception that ART is effective and self-reported risky sexual behaviors. Disinhibition behaviors are less likely among persons living with HIV/AIDS than among the general population (at least as defined in this study), that is, family members of persons living with HIV/AIDS and respondents from households with no identified HIV positive individual. Our findings are robust to controlling for individual fixed effects, time-varying community level unobservable characteristics, and time-varying household unobservable characteristics. Our specifications, however, cannot account for time-varying unobserved individual characteristics. Our results should therefore be interpreted with this potential source of endogeneity in mind. Nevertheless, the association that we estimate appears strong enough to suggest that increased access to ART without prevention programs may lead to increased unsafe sexual behaviors.

The remainder of the paper is organized as follows. In Section II, we provide a conceptual framework to motivate our empirical work. In Section III, we discuss our survey and summarize the main variables used in the analysis. We discuss our empirical strategy in Section IV and report our estimation results in Section V. Section VI concludes.

\section{Access to ART and Risky Sexual Behavior}

When people become aware of ART, they may adjust their sexual behavior to account for the decline in the costliness of the newly treatable disease. Such a

\footnotetext{
5 The authors define risk compensation as increased sexual risk when ART is available.

${ }^{6}$ Cohen et al. (2009) conduct their field survey in two steps. First, they administer a survey including questions on sexual behaviors and perceptions on ART. The second step consists of HIV testing of respondents. Note that individuals who knew their sero-prevalence were excluded from the sample. The approach prevents respondents from associating their answers to the HIV test and therefore adjusting the formers. However, it does not solve the issue associated with unobservable individual characteristics.
} 
response may create a compensation effect that exacerbates HIV transmission and thus partially reduces the benefits of expanded treatment. Such possible offsetting behaviors have been discussed in the economic literature in the context of other safety (e.g., Peltzman 1975) and health issues (e.g., Oza 2009).?

We assume that individuals derive utility from both safe sex and risky sex (e.g., unprotected sex with non-coresiding partner). Moreover, the marginal utility of risky sex is greater than that of safe sex. ${ }^{8}$ The cost of risky sex is, however, higher than that of safe sex. In particular, the cost of risky sex includes the probability of contracting HIV and the ensuing disutility from developing AIDS (this includes the physical pain after the individual develops AIDS, the monetary costs from lost earnings, stigma, premature death, etc.). ${ }^{9}$ If the consumer is maximizing her utility subject to a budget constraint, standard economic reasoning implies that at the optimum, the ratio of the marginal utility and the cost is equalized between safe sex and unprotected sex.

Assume that, prior to the availability of ART, a sexually active population is aware of the danger of HIV infection from unprotected sex and has selected an optimal mix of safe and risky sexual behavior that equates the ratio of the marginal utility to the "cost" of the two behaviors. From this starting position, a change in policy that increases people's confidence that ART is accessible and effective lowers the cost of risky sex compared to that of safe sex. The effect is an increase in the demand for risky sex, as the basic law of demand would predict. To the extent that risky sex and safe sex are substitutes, we would expect a decrease in the demand for safe sex as people become more confident of ART's availability and efficacy (i.e., the perceived private cost or "price" of risky sex decreases, while everything else is kept constant).

\footnotetext{
7 A long-debated issue is the introduction of seat belts in cars in the United States. For instance, Lave and Weber (1970) and Peltzman (1975) argued that seat belt use might produce careless driving and in turn greater risks for nonoccupants. As a result, mandatory seat belt laws might increase total fatalities rather than reduce them. However, empirical analyses focusing on the safety regulation of motorized vehicles have generated mixed results. For instance, Cohen and Einav (2003) found that while seat belts usage has a small negative effect on traffic fatalities, there is no evidence suggesting that seat belts usage increases reckless driving. In contrast, using data from recreational boats, McCarthy and Talley (1999) found that the passenger was less likely to wear a personal flotation device (PFD) when the driver had received formal training. Oza (2009) hypothesizes that the introduction of over-the-counter access to the "morning after pill" lowered the risk of unintended pregnancies but also lowered the opportunity costs of unprotected sex. She shows that for women who were exposed to the policy, abortion rates decreased while STIs increased, hence corroborating disinhibition behaviors.

${ }^{8}$ Rao et al. (2003) found that prostitutes in Calcutta who agree to condom-free sex are paid more, implying that clients derive more satisfaction from condom-free sex. Gertler, Shah, and Bertozzi (2005) found similar results using data from the states of Morelos and Michoacan in Mexico.

9 We abstract from other sexually transmitted diseases and birth control.
} 
This framework, while overly simplified, provides a context for interpreting our empirical results. The usual presumption is that ART scale-up will create and reinforce a popular perception that AIDS is less threatening. However, the news that a country is rolling out free and effective ART might also create unwarranted optimism about the accessibility and efficacy of AIDS treatment, such that the eventual experience of local ART availability reduces rather than increases the population's confidence that AIDS is treatable. Considering our independent variables, we argue that the cost of risky sex is lower when people believe, rightly or wrongly, that increased access to ART has made it easier for them individually to manage or even to cure HIV/AIDS. Thus, we hypothesize a positive association between risky sexual behavior and perceived ARTefficacy. Furthermore, if accumulated experience with local ART service delivery increases (decreases) the population's confidence that ART "works," then safe sex (abstinence or condom use) would react negatively (positively) to increased local experience with ART.

Obviously this framework leaves out adjustments in sexual behavior that could limit disinhibition. An important externality of ART is that it increases the private benefits of testing and therefore leads to increased demand for testing. As mentioned earlier, people who discover that they are HIV negative would logically decrease their demand for risky sex, especially if prevalence is high among potential sexual partners (e.g., Ahituv, Hotz, and Philipson 1996). However, other studies have shown a positive association between an HIVnegative test result and subsequent risky sexual behavior (e.g., Clark et al. 1998; Wang et al. 2007; Kabiru et al. 2010), perhaps because people who know they have taken risks and learn they are uninfected mistakenly conclude they are immune. Further consideration of HIV testing is beyond the scope of this paper.

\section{Context and Data}

The primary goal of the Treatment Acceleration Program was to pilot strategies for strengthening each participant country's capacity to scale up comprehensive programs providing care and treatment, and it ran from 2004 to 2008. The pilot treatment system ensured that people living with HIV/AIDS (PLWHA) and their immediate families benefit from care and treatment. The TAP resulted in the increase of both HIV/AIDS treatment centers and number of AIDS patients under treatment (ACTAfrica and Global HIV Program 2007). The number of patients receiving ART increased from 88,211 in December 2007 to above 128,000 patients in December 2008 (Mozambique Ministry of Health 2009). Conceivably, more people would have become more aware of ART during this period because access to ART was being scaled up. Figure 2 


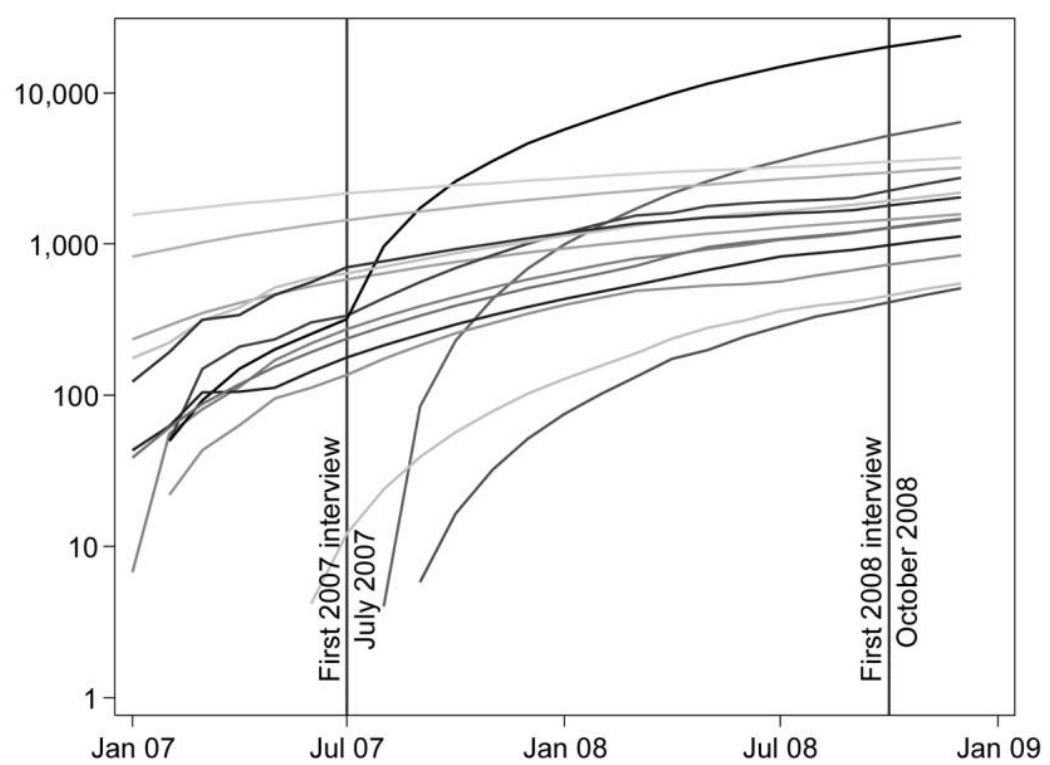

Figure 2. Cumulated experience initiating ART patients for the 14 facilities observed in both survey waves and matched to survey households.

shows the scale-up in the 14 public health facilities that match our household sample in both waves of data collection, measured as the cumulated number of patients ever initiated on ART.

The data were collected in 2007 and 2008 in four provinces of Mozambique (Maputo City, Maputo Province, Sofala, Manica). ${ }^{10}$ The HIV positive persons of the survey were sampled at the health facility where they received treatment or were in line to receive treatment at a later date. These patients were interviewed at home along with their household members. A group of households in which there were no identified HIV positive persons were also sampled to control for common trends in socioeconomic circumstances. These households were randomly selected in the neighborhood of each household with at least one identified HIV positive person.

The first wave of the survey, conducted between August and December of 2007, included 658 HIV households and 341 matching households. In the second wave, one year later, HIV households that could not be found and interviewed were not replaced, but matching households were. The panel consists of 896 households interviewed in both waves: 616 HIV households

10 Five ART clinics were sampled in the city of Maputo, seven ART clinics were sampled in the province of Maputo (besides the city), four ART clinics were sampled in the province of Sofala, and two ART clinics were sampled in the province of Manica. 
and 280 matching households. For the analysis, we restrict the sample to men aged between 15 and 55 and women aged between 15 and 49. This corresponds to 1,807 individuals at baseline and 1,917 individuals at followup. At baseline, there were 1,134 and 673 individuals in the treatment and in the comparison groups, respectively. At follow-up, there were 1,208 individuals in the treatment group and 709 individuals in the treatment groups.

Respondents were asked about their sexual behavior and their beliefs about whether AIDS could be cured or treated by ART. Questions on sexual behaviors include the number of sexual partners during the 12 months preceding the survey, the relationship to each sexual partner, and whether a condom was used during the last sexual act with that partner. All our variables, in particular the sexual behaviors, are self-reported.

Our analysis uses three dependent variables measuring different aspects of unsafe sexual behavior: "casual" stands for casual sex and is an indicator for any sexual intercourse during the last 12 months with a nonregular partner, ${ }^{11}$ "risky" stands for risky sex and is defined as unprotected sex with a noncohabiting partner during the last 12 months, and abstinence is the absence of sexual relationship over the last 12 months. On the right-hand side, our main variable of interest is "AIDSeasy" (perceived efficacy of ART) a measure of an individual's perception of how easily AIDS can be tackled. The variable is defined as follows: it is equal to 2 if the individual believes (wrongly) that AIDS is curable, equal to 1 if the individual believes (correctly) that AIDS can be treated but is not curable, and equals to 0 if he believes (wrongly) that AIDS is not treatable.

We summarize the key variables in table 1 . From column 1, it appears that a large proportion of respondents engage in casual sex: about 34\% in 2007 and $32 \%$ in 2008. Persons living with HIV are, however, less likely to engage in casual sex. Fewer respondents (7.4\% in 2007 and in 2008) engage in unprotected casual sex. The substantial difference between columns 1 and 2 suggests that when people engage in sexual intercourse with non-coresiding partners, they are likely to use a condom.

Abstinence is practiced by around $18 \%$ and $16 \%$ of the sample in 2007 and in 2008, respectively, suggesting a rather high sexual activity. This would suggest that in addition to promoting abstinence and fidelity, prevention programs should focus also on the use of condoms since abstinence is low and casual sex is relatively high. The low rate of unprotected sex with non-

11 For the analysis, relationships are reduced to two categories: coresiding partners (whether legally married or not) and all other partners. 
TABLE 1

DESCRIPTIVE STATISTICS

\begin{tabular}{|c|c|c|c|c|c|c|c|c|}
\hline & $\begin{array}{l}\text { Casual } \\
\text { (1) }\end{array}$ & $\begin{array}{l}\text { Risky } \\
\text { (2) }\end{array}$ & $\begin{array}{c}\text { Abstinence } \\
\text { (3) }\end{array}$ & $\begin{array}{l}\text { AIDS } \\
\text { Curable } \\
\text { (4) }\end{array}$ & $\begin{array}{c}\text { AIDS } \\
\text { Treatable } \\
\text { (5) }\end{array}$ & $\begin{array}{l}\text { AIDSeasy } \\
\text { (6) }\end{array}$ & $\begin{array}{c}\text { Age } \\
(7)\end{array}$ & $\begin{array}{c}\text { Female } \\
\text { (8) }\end{array}$ \\
\hline & \multicolumn{8}{|c|}{ A. First Wave (2007) } \\
\hline Pooled sample & $\begin{array}{c}.341 \\
{[.005]}\end{array}$ & $\begin{array}{c}.074 \\
{[.009]}\end{array}$ & $\begin{array}{l}.177 \\
{[.007]}\end{array}$ & $\begin{array}{l}.064 \\
{[.005]}\end{array}$ & $\begin{array}{l}.872 \\
{[.007]}\end{array}$ & $\begin{array}{l}.937 \\
{[.008]}\end{array}$ & $\begin{array}{r}29.412 \\
{[.207]}\end{array}$ & $\begin{array}{c}.537 \\
{[.010]}\end{array}$ \\
\hline HIV+ persons & $\begin{array}{l}.260 \\
{[.008]}\end{array}$ & $\begin{array}{c}.039 \\
{[.018]}\end{array}$ & $\begin{array}{c}.354 \\
{[.020]}\end{array}$ & $\begin{array}{l}.086 \\
{[.012]}\end{array}$ & $\begin{array}{l}.933 \\
{[.010]}\end{array}$ & $\begin{array}{l}1.019 \\
{[.016]}\end{array}$ & $\begin{array}{r}36.200 \\
{[.355]}\end{array}$ & $\begin{array}{c}.620 \\
{[.020]}\end{array}$ \\
\hline Family of HIV+ & $\begin{array}{l}.355 \\
{[.008]}\end{array}$ & $\begin{array}{c}.073 \\
{[.014]}\end{array}$ & $\begin{array}{l}.122 \\
{[.010]}\end{array}$ & $\begin{array}{l}.068 \\
{[.007]}\end{array}$ & $\begin{array}{l}.888 \\
{[.009]}\end{array}$ & $\begin{array}{l}.956 \\
{[.012]}\end{array}$ & $\begin{array}{r}26.516 \\
{[.304]}\end{array}$ & $\begin{array}{c}.511 \\
{[.015]}\end{array}$ \\
\hline \multirow[t]{2}{*}{ Comp. hh } & $\begin{array}{c}.376 \\
{[.010]}\end{array}$ & $\begin{array}{c}.099 \\
{[.016]}\end{array}$ & $\begin{array}{l}.130 \\
{[.011]}\end{array}$ & $\begin{array}{l}.045 \\
{[.007]}\end{array}$ & $\begin{array}{l}.811 \\
{[.013]}\end{array}$ & $\begin{array}{r}.856 \\
{[.016]}\end{array}$ & $\begin{array}{r}28.685 \\
{[.340]}\end{array}$ & $\begin{array}{l}.516 \\
{[.017]}\end{array}$ \\
\hline & \multicolumn{8}{|c|}{ B. Second Wave (2008) } \\
\hline Pooled sample & $\begin{array}{c}.320 \\
{[.005]}\end{array}$ & $\begin{array}{l}.074 \\
{[.009]}\end{array}$ & $\begin{array}{l}.159 \\
{[.007]}\end{array}$ & $\begin{array}{l}.052 \\
{[.004]}\end{array}$ & $\begin{array}{c}.743 \\
{[.009]}\end{array}$ & $\begin{array}{l}.795 \\
{[.010]}\end{array}$ & $\begin{array}{r}29.719 \\
{[.216]}\end{array}$ & $\begin{array}{c}.525 \\
{[.010]}\end{array}$ \\
\hline HIV+ persons & $\begin{array}{c}.236 \\
{[.008]}\end{array}$ & $\begin{array}{c}.035 \\
{[.019]}\end{array}$ & $\begin{array}{c}.324 \\
{[.021]}\end{array}$ & $\begin{array}{c}.057 \\
{[.010]}\end{array}$ & $\begin{array}{c}.819 \\
{[.017]}\end{array}$ & $\begin{array}{c}.876 \\
{[.021]}\end{array}$ & $\begin{array}{c}37.059 \\
{[.376]}\end{array}$ & $\begin{array}{c}.623 \\
{[.022]}\end{array}$ \\
\hline Family of HIV+ & $\begin{array}{l}.326 \\
{[.009]}\end{array}$ & $\begin{array}{l}.084 \\
{[.014]}\end{array}$ & $\begin{array}{l}.111 \\
{[.010]}\end{array}$ & $\begin{array}{l}.060 \\
{[.007]}\end{array}$ & $\begin{array}{l}.724 \\
{[.014]}\end{array}$ & $\begin{array}{l}.784 \\
{[.017]}\end{array}$ & $\begin{array}{r}26.970 \\
{[.327]}\end{array}$ & $\begin{array}{c}.487 \\
{[.016]}\end{array}$ \\
\hline Comp. hh & $\begin{array}{c}.362 \\
{[.009]}\end{array}$ & $\begin{array}{c}.083 \\
{[.016]}\end{array}$ & $\begin{array}{c}.121 \\
{[.011]}\end{array}$ & $\begin{array}{c}.039 \\
{[.007]}\end{array}$ & $\begin{array}{c}.723 \\
{[.015]}\end{array}$ & $\begin{array}{c}.762 \\
{[.017]}\end{array}$ & $\begin{array}{c}28.757 \\
{[.333]}\end{array}$ & $\begin{array}{c}.513 \\
{[.017]}\end{array}$ \\
\hline
\end{tabular}

Note. Robust standard errors in brackets. Comp. hh = comparison households.

coresiding partners is by itself encouraging from the disease containment perspective. Overall, between the 2007 and the 2008 panels, the descriptive statistics reveal a general decline in casual and risky sex, but also a decline in abstinence.

ART perceived efficacy variables are summarized in columns 5-7 of table 1. About 6\% of respondents in 2007 and 55\% in 2008 report that AIDS can be cured by ART, while around $80 \%$ report that AIDS can be treated but cannot be cured by ART. The proportion of respondents (especially those living with HIV) who believed that AIDS could be cured by ART declined slightly between 2007 and 2008. We observe the same pattern for "AIDS can be treated." Compared to 2007, fewer respondents believe that AIDS can be treated in 2008. It is plausible that people adjust their beliefs about the true nature of ART over time as they are more exposed to ART. In the AIDSeasy variable, the perceptions or beliefs are not ordered by whether they are factually correct or incorrect but rather by the degree to which the individual believes that AIDS can easily be managed. ${ }^{12}$ Overall, the pattern over time is consistent with the pattern that we observed for the two separate measures of ART

12 While we think this is the most useful specification for our analysis of disinhibition behavior, for robustness, we present in appendix tables A1-A6 similar analyses where we have entered "AIDS can be cured" and "AIDS can be treated" as separate independent variables. 


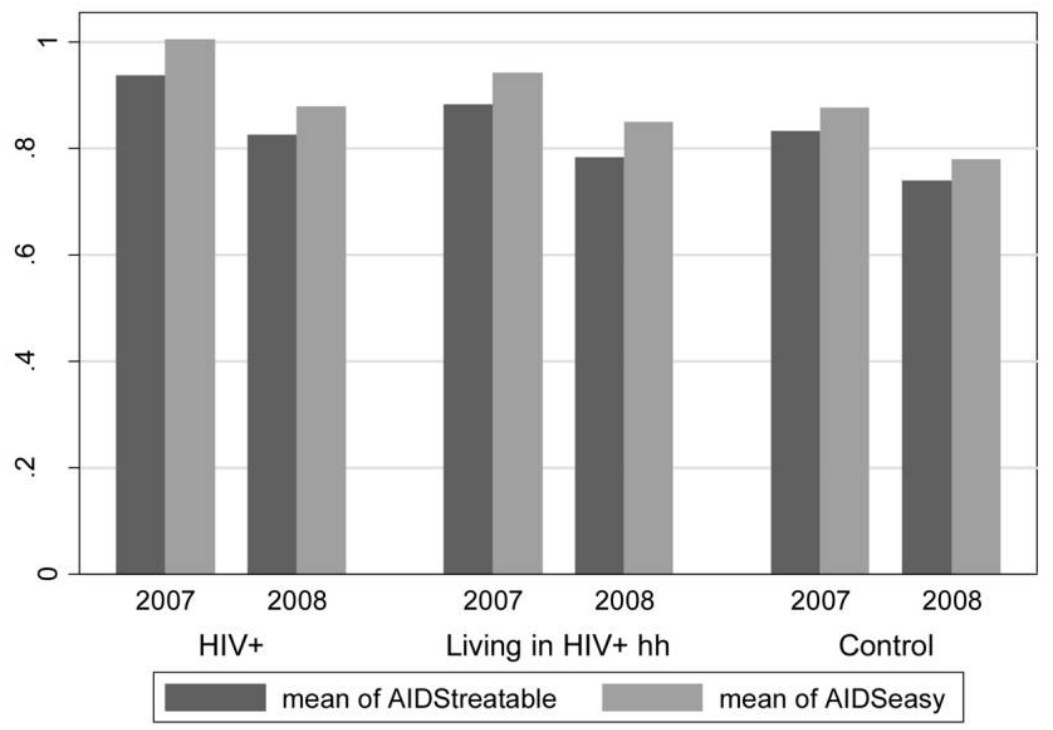

Figure 3. The proportion of respondents believing that AIDS is treatable or curable decline for all groups between the two waves of the survey.

perceived efficacy. Between the two survey rounds, as shown in figure 3, all three groups of people become to some degree disillusioned about the benefits of ART.

\section{Empirical Strategy}

The general hypothesis we want to test is whether ART perceived efficacy increases risky sexual behavior, that is, whether there is a behavioral disinhibition or risk compensation. Our primary interest is estimating how individuals adjust their sexual behavior as they become aware of ART and form their perceptions on how effective ART is at treating AIDS or (falsely) at curing AIDS. A positive association of perceived efficacy of ART (AIDSeasy) with casual sex and risky sex and a negative association with abstinence would provide suggestive evidence of disinhibition behavior. To proceed, we specify the following regression.

$$
y_{i t}=\beta_{0}+\beta_{1} A_{i t}+\beta_{2} X_{i t}+\beta_{3} \text { Follow-up }+\delta_{i}+\varepsilon_{i t},
$$

where $y$ is a behavioral outcome, $A$ is a variable summarizing the perceived efficacy of ART, and $X$ summarizes other variables that could influence sexual behavior, $t$ indexes time periods (2007 and 2008), and $i$ indexes individuals. In this specification, $\delta$ is a time-constant individual level variable which is unobserved and which may be correlated with $A$. 
Obviously, perceived efficacy of ART is likely endogenous in regression (1) since unobserved variables absorbed in the error term may also be correlated with ART perceived efficacy. Such unobserved variables can be categorized in three types. First, there are unobserved time-invariant individual characteristics. For instance, people who engaged in risky sex may have an incentive to seek out information about ART. The resulting spurious positive association between risky sexual behaviors and the perceived efficacy of ART would create an upward bias. Conversely, people who engage in risky sex may be in denial about HIV/AIDS and therefore less aware of treatment possibilities, creating a negative association between risky sexual behavior and the perceived efficacy of ART, hence a downward bias. It is quite plausible that these two effects could offset each other so that $\beta_{1}=0$. Because of the panel structure of our data, we can use individual fixed effects $(\delta)$ to control for unobservable time-invariant individual characteristics.

Second, between the two survey rounds, treatment and other prevention programs may have expanded faster in some communities than in others. Such scale-ups could affect both perceived efficacy of ART and sexual behaviors. Because these changes occur over time, they are not controlled for by the inclusion of individual fixed effects in our regressions. Instead, we use time indicators interacted with health facility indicators to control for community level time-varying variables, including both observed and unobserved variables. ${ }^{13}$ We estimate the following regression:

$$
y_{i t}=\beta_{0}+\beta_{1} A_{i t}+\beta_{2} X_{i t}+\beta_{3} \text { Follow-up }+\delta_{i}+\lambda_{t \times h f}+\varepsilon_{i t},
$$

where $\lambda_{t^{\times} b f}$ indicates time and health facility interaction terms, and all other variables are as previously defined. Since our household sample was constituted starting from a list of patients at the health facility level, we use health facility indicators as indicators of the catchment area or community surrounding the health facility.

The third source of endogeneity is time-varying individual unobserved characteristics. Time-varying individual fixed effects that are both correlated with sexual behavior and perceived efficacy of ART would still bias our estimations. This would be the case if, for example, ART scale-up influences unobservable characteristics such as the discount factor or "taste for risky sex." Alternatively, individuals could learn new information that affects both perceived efficacy of ART and sexual behaviors. Unfortunately, absent valid instruments we cannot address this last source of endogeneity. However, we

13 This is akin to the specification of aggregate shocks in the consumption-smoothing literature (e.g., Kazianga and Udry 2006). 


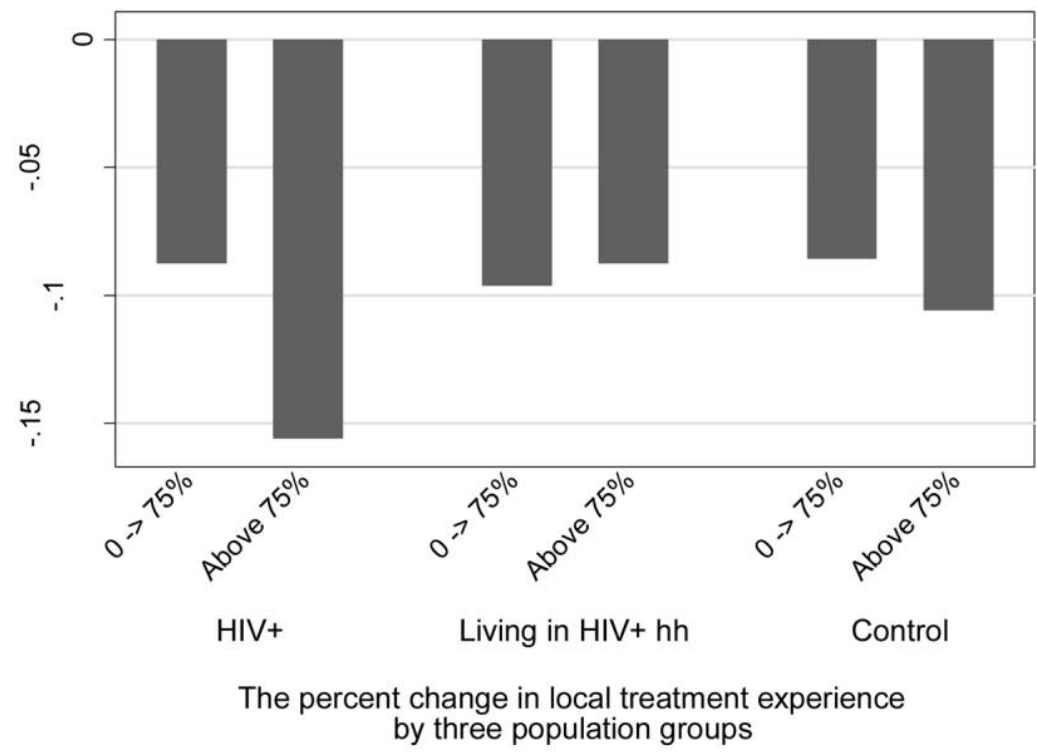

Figure 4. Among two of three groups change in perception that ART is "easy" is negatively associated with the percent change in local treatment experience.

observed more than one individual in each household in each of the two rounds. Hence, we can use household fixed effects interacted with time dummies to control for time-varying household level unobservables.

$$
y_{i t}=\beta_{0}+\beta_{1} A_{i t}+\beta_{2} X_{i t}+\beta_{3} \text { Follow-up }+\delta_{i}+\gamma_{t \times h b}+\varepsilon_{i t},
$$

where $\lambda_{t^{\star} \times b}$ indicates time and household interaction terms, and all other variables are as previously defined. This does not eliminate the concern with time-varying individual level unobservables, but it provides a rough idea on whether the association would remain significant if time-varying individual level unobserved characteristics were controlled for.

Our different specifications do not identify a causal relation between ART perceived efficacy and sexual behaviors. Instead, a statistically significant $\beta_{2}$ across alternative specifications would suggest a rather robust association between ART perceived efficacy and sexual behavior. At the most, we could show that such association is robust to time-constant individual unobservable characteristics and to time-varying community and household level unobservable characteristics.

As discussed above, our AIDSeasy variable measuring the individual's perception of the efficacy of ART is correlated in our sample with a community's accumulated experience with ART, a variable we call cumestpts. Figure 4 displays the average change in the AIDSeasy score between the two 
rounds of the survey for all three groups, each subdivided according to how great an increase in treatment experience had occurred in that group. Consistent with table 1, all six bars show a decline in the "AIDSeasy" score between survey rounds, suggesting that disillusionment with ART was general in this area of Mozambique at this time. For two of the three groups, those with HIV infection and those in the surrounding neighborhood, the degree of disillusionment was greater when the percentage increase in treatment experience was greater than $75 \%$.

\section{Results and Discussion}

Table 2 shows results for the entire sample with individual fixed effects controlling for unobservable time-invariant characteristics at the individual and community levels. The results are presented separately for men and women. AIDSeasy is positively associated with casual sex for both men (col. 1) and women (col. 2). The same positive association is found for risky sex, although it is only significant for women (col.4). The coefficients on abstinence are negative but not statistically significant. Taken together, these results suggest a robust positive association between perceptions that ART is efficacious with riskier sexual behaviors. The suggestion is strong that the decline in confidence in AIDS treatment between survey rounds measured by declining average values of our variable AIDSeasy is associated in the data with a decline in risky sexual behavior.

AIDSeasy is, however, an endogenous variable. Hence our specification with individual fixed effects can only control for time-invariant unobservable characteristics. By adding to the specifications interaction terms between community (health facility) fixed effects and an indicator for the survey round, table 3 allows us to further account for time-varying unobservable characteristics at the community/health facility level. Overall, the results in table 3 are very similar to the results described in table 2: AIDSeasy is positively associated with casual sex for both men (col. 1) and women (col. 2), and with risky sex for women (col. 4). The coefficients are not statistically significant for abstinence (cols. 5 and 6).

Table 4 goes one step further in attempting to account for time-varying unobservable characteristics by adding to the individual fixed effects a set of interaction terms between household fixed effects and an indicator for the survey round. While, with the exception for abstinence, the associations have the same signs as in table 2, several coefficients lose their statistical significance in table 4. However, the results still indicate a statistically positive association between AIDSeasy and casual sex for men (statistically significant at $10 \%)$. 
TABLE 2

THE ASSOCIATION BETWEEN PERCEPTIONS ABOUT AIDS AND SEXUAL BEHAVIORS, CONTROLLING FOR INDIVIDUAL FIXED EFFECTS

\begin{tabular}{|c|c|c|c|c|c|c|}
\hline & \multicolumn{2}{|c|}{ Casual } & \multicolumn{2}{|c|}{ Risky } & \multicolumn{2}{|c|}{ Abstinence } \\
\hline & $\begin{array}{l}\text { Men } \\
(1)\end{array}$ & $\begin{array}{l}\text { Women } \\
\text { (2) }\end{array}$ & $\begin{array}{l}\text { Men } \\
(3)\end{array}$ & $\begin{array}{l}\text { Women } \\
\text { (4) }\end{array}$ & $\begin{array}{l}\text { Men } \\
(5)\end{array}$ & $\begin{array}{c}\text { Women } \\
\text { (6) }\end{array}$ \\
\hline \multirow[t]{2}{*}{ AIDSeasy } & $.1031^{\text {*** }}$ & $.0691^{\star \star \star}$ & .0256 & $.0462^{\star \star}$ & -.0165 & -.0068 \\
\hline & {$[.027]$} & {$[.022]$} & {$[.025]$} & {$[.019]$} & {$[.035]$} & [.032] \\
\hline \multirow[t]{2}{*}{ Follow-up } & -.0008 & .0029 & -.0008 & .0196 & -.0364 & -.0033 \\
\hline & {$[.018]$} & {$[.037]$} & {$[.013]$} & {$[.018]$} & [.029] & {$[.045]$} \\
\hline \multirow[t]{2}{*}{ age } & .0079 & $.1051^{\star}$ & .0084 & .0403 & $.0748^{\star}$ & -.0451 \\
\hline & {$[.049]$} & {$[.057]$} & {$[.024]$} & {$[.026]$} & {$[.040]$} & {$[.060]$} \\
\hline \multirow[t]{2}{*}{ age2 } & .0002 & $-.0014^{\star \star}$ & .0000 & -.0005 & -.0008 & .0007 \\
\hline & {$[.001]$} & {$[.001]$} & {$[.000]$} & [.000] & {$[.001]$} & {$[.001]$} \\
\hline \multirow[t]{2}{*}{ Constant } & -.2002 & -1.4507 & -.2220 & -.6471 & $-1.2169 *$ & .9160 \\
\hline & {$[.888]$} & [1.124] & [.459] & {$[.415]$} & {$[.651]$} & [1.216] \\
\hline Observations & 2,350 & 2,663 & 2,350 & 2,663 & 2,350 & 2,663 \\
\hline$R^{2}$ & .800 & .785 & .657 & .663 & .710 & .680 \\
\hline
\end{tabular}

Note. Robust standard errors in brackets, clustered at the health facility level. AIDSeasy is defined as follows: $=2$ if the individual believes that AIDS is curable, $=1$ if individual believes that AIDS can be treated but is not curable, and $=0$ if he believes that AIDS is not treatable. Casual sex is any sexual intercourse with a nonregular partner, risky is defined as unprotected sex with a noncohabiting partner, and abstinence is defined over the last 12 .

$\star p<.10$.

$\star * \quad p<.05$.

$\star \star \star ~ p<.01$.

TABLE 3

THE ASSOCIATION BETWEEN PERCEPTIONS ABOUT AIDS AND SEXUAL BEHAVIORS, CONTROLLING FOR INDIVIDUAL FIXED EFFECTS AND TIME-VARYING COMMUNITY/HEALTH FACILITY LEVEL UNOBSERVABLES

\begin{tabular}{|c|c|c|c|c|c|c|}
\hline & \multicolumn{2}{|c|}{ Casual } & \multicolumn{2}{|c|}{ Risky } & \multicolumn{2}{|c|}{ Abstinence } \\
\hline & $\begin{array}{l}\text { Men } \\
(1)\end{array}$ & $\begin{array}{l}\text { Women } \\
\text { (2) }\end{array}$ & $\begin{array}{l}\text { Men } \\
\text { (3) }\end{array}$ & $\begin{array}{l}\text { Women } \\
\text { (4) }\end{array}$ & $\begin{array}{l}\text { Men } \\
(5)\end{array}$ & $\begin{array}{l}\text { Women } \\
\text { (6) }\end{array}$ \\
\hline \multirow[t]{2}{*}{ AIDSeasy } & $.1114^{\star \star \star}$ & $.0601^{\star \star}$ & .0275 & $.0479 * *$ & -.0209 & .0066 \\
\hline & {$[.028]$} & {$[.027]$} & {$[.024]$} & {$[.020]$} & {$[.038]$} & [.028] \\
\hline \multirow[t]{2}{*}{ Follow-up } & -.0357 & $-.3197^{\star \star \star}$ & -.0163 & .0116 & .0179 & $.3372^{\star \star \star}$ \\
\hline & {$[.022]$} & {$[.030]$} & {$[.016]$} & {$[.011]$} & {$[.027]$} & {$[.029]$} \\
\hline \multirow[t]{2}{*}{ age } & -.0001 & $.1004^{*}$ & .0056 & .0361 & .0688 & -.0459 \\
\hline & {$[.049]$} & {$[.059]$} & {$[.023]$} & {$[.025]$} & {$[.043]$} & {$[.064]$} \\
\hline \multirow[t]{2}{*}{ age2 } & .0003 & $-.0013^{\star}$ & .0001 & -.0004 & -.0007 & .0006 \\
\hline & {$[.001]$} & {$[.001]$} & {$[.000]$} & [.000] & {$[.001]$} & {$[.001]$} \\
\hline \multirow{2}{*}{ Constant } & -.0423 & -1.0986 & -.2172 & -.5900 & -1.2026 & .6385 \\
\hline & {$[.915]$} & [1.148] & {$[.460]$} & [.399] & {$[.721]$} & [1.282] \\
\hline Observations & 2,350 & 2,663 & 2,350 & 2,663 & 2,350 & 2,663 \\
\hline$R^{2}$ & .803 & .790 & .660 & .668 & .719 & .693 \\
\hline
\end{tabular}

Note. Robust standard errors in brackets, clustered at the health facility level. AIDSeasy is defined as follows: $=2$ if the individual believes that AIDS is curable, $=1$ if individual believes that AIDS can be treated but is not curable, and $=0$ if he believes that AIDS is not treatable. Casual sex is any sexual intercourse with a nonregular partner, risky is defined as unprotected sex with a noncohabiting partner, and abstinence is defined over the last 12

$\star p<.10$.

** $p<.05$.

$\star \star \star ~ p<.01$.

This content downloaded from 139.078.028.086 on March 19, 2019 14:50:37 PM

All use subject to University of Chicago Press Terms and Conditions (http://www.journals.uchicago.edu/t-and-c). 
TABLE 4

THE ASSOCIATION BETWEEN PERCEPTIONS ABOUT AIDS AND SEXUAL BEHAVIORS, CONTROLLING FOR INDIVIDUAL FIXED EFFECTS AND TIME-VARYING HOUSEHOLD LEVEL UNOBSERVABLES

\begin{tabular}{|c|c|c|c|c|c|c|}
\hline & \multicolumn{2}{|c|}{ Casual } & \multicolumn{2}{|c|}{ Risky } & \multicolumn{2}{|c|}{ Abstinence } \\
\hline & $\begin{array}{l}\text { Men } \\
(1)\end{array}$ & $\begin{array}{c}\text { Women } \\
\text { (2) }\end{array}$ & $\begin{array}{l}\text { Men } \\
(3)\end{array}$ & $\begin{array}{c}\text { Women } \\
\text { (4) }\end{array}$ & $\begin{array}{c}\text { Men } \\
\text { (5) }\end{array}$ & $\begin{array}{c}\text { Women } \\
\text { (6) }\end{array}$ \\
\hline \multirow[t]{2}{*}{ AIDSeasy } & $.2417^{*}$ & .1535 & .0337 & .0883 & -.0106 & .0145 \\
\hline & {$[.142]$} & {$[.101]$} & {$[.082]$} & {$[.137]$} & {$[.123]$} & {$[.060]$} \\
\hline \multirow[t]{2}{*}{ Follow-up } & -.0186 & .0161 & $-1.1509^{\star \star \star}$ & -.0310 & .0538 & -.0569 \\
\hline & {$[.311]$} & {$[.186]$} & {$[.143]$} & {$[.081]$} & {$[.292]$} & {$[.227]$} \\
\hline \multirow[t]{2}{*}{ age } & .0008 & .1273 & -.0649 & .0186 & .0380 & -.0307 \\
\hline & {$[.102]$} & {$[.140]$} & {$[.051]$} & [.091] & {$[.126]$} & [.156] \\
\hline \multirow[t]{2}{*}{ age2 } & -.0000 & -.0020 & .0008 & -.0005 & -.0005 & .0002 \\
\hline & {$[.001]$} & [.002] & {$[.001]$} & {$[.001]$} & [.002] & {$[.002]$} \\
\hline \multirow[t]{2}{*}{ Constant } & .1623 & -1.6506 & $1.9340^{*}$ & -.0609 & -.5227 & .9405 \\
\hline & [2.003] & [2.762] & {$[.983]$} & [1.534] & {$[2.313]$} & [3.331] \\
\hline Observations & 2,350 & 2,663 & 2,350 & 2,663 & 2,350 & 2,663 \\
\hline$R^{2}$ & .933 & .927 & .871 & .888 & .919 & .913 \\
\hline
\end{tabular}

Note. Robust standard errors in brackets, clustered at the health facility level. AIDSeasy is defined as follows: $=2$ if the individual believes that AIDS is curable, $=1$ if individual believes that AIDS can be treated but is not curable, and $=0$ if he believes that AIDS is not treatable. Casual sex is any sexual intercourse with a nonregular partner, risky is defined as unprotected sex with a noncohabiting partner, and abstinence is defined over the last 12 .

$\star p<.10$.

$\star * \quad p<.05$.

$\star \star \star ~ p<.01$.

Tables 2-4 report results of regressions using the entire sample. However, our sample contains three distinct subsamples: individuals known to be living with HIV/AIDS, family members of those individuals, and members of neighboring households. These three groups should have very different perceptions about AIDS and might also react differently to those different perceptions. A separate analysis for each of these three groups does therefore allow a finer analysis of potential disinhibition behaviors. We take our specification in table 4, which goes the furthest in attempting to control for time-variant endogeneity and we apply it separately to those three groups in tables 5-7.

Table 5 focuses on individuals identified in our sample as living with HIV/ AIDS. Because in most households there is only one individual identified as living with HIV/AIDS, we cannot apply for this subsample the specification in table 4 adding interaction terms between household fixed effects and an indicator for the survey round. Instead, we revert to the specification in table 3 adding interaction terms between community/health facility fixed effects and an indicator for the survey round. None of the coefficients on AIDSeasy in table 5 are statistically significant. This suggests that disinhibition behaviors are not found among individuals living with HIV/AIDS. 
TABLE 5

THE ASSOCIATION BETWEEN PERCEPTIONS ABOUT AIDS AND SEXUAL BEHAVIORS AMONG INDIVIDUALS LIVING WITH HIV/AIDS, CONTROLLING FOR INDIVIDUAL FIXED EFFECTS AND TIME-VARYING COMMUNITY/HEALTH FACILITY LEVEL UNOBSERVABLES

\begin{tabular}{|c|c|c|c|c|c|c|}
\hline & \multicolumn{2}{|c|}{ Casual } & \multicolumn{2}{|c|}{ Risky } & \multicolumn{2}{|c|}{ Abstinence } \\
\hline & $\begin{array}{l}\text { Men } \\
(1)\end{array}$ & $\begin{array}{l}\text { Women } \\
\text { (2) }\end{array}$ & $\begin{array}{l}\text { Men } \\
\text { (3) }\end{array}$ & $\begin{array}{c}\text { Women } \\
\text { (4) }\end{array}$ & $\begin{array}{l}\text { Men } \\
(5)\end{array}$ & $\begin{array}{c}\text { Women } \\
\text { (6) }\end{array}$ \\
\hline \multirow[t]{2}{*}{ AIDSeasy } & -.0064 & .0258 & .0246 & -.0305 & -.0573 & .0037 \\
\hline & [.099] & [.049] & {$[.025]$} & {$[.024]$} & {$[.064]$} & {$[.042]$} \\
\hline \multirow[t]{2}{*}{ Follow-up } & -.0231 & .0047 & $-.0357^{\star \star \star}$ & -.0165 & -.0056 & $-.9100^{\star \star \star}$ \\
\hline & {$[.021]$} & [.114] & {$[.012]$} & {$[.022]$} & {$[.033]$} & {$[.047]$} \\
\hline \multirow[t]{2}{*}{ age } & $-.3416^{\star \star \star}$ & .0560 & .0668 & -.0336 & $.2559^{\star}$ & .1023 \\
\hline & {$[.101]$} & {$[.184]$} & {$[.053]$} & {$[.052]$} & [.126] & {$[.100]$} \\
\hline \multirow[t]{2}{*}{ age2 } & $.0043^{\star \star \star}$ & -.0012 & -.0004 & .0004 & $-.0029^{\star}$ & -.0003 \\
\hline & {$[.001]$} & {$[.002]$} & {$[.001]$} & {$[.001]$} & {$[.002]$} & {$[.002]$} \\
\hline \multirow[t]{2}{*}{ Constant } & $6.7072^{\star \star \star}$ & -.2278 & $-2.0808^{*}$ & .7601 & $-5.0077^{\star \star}$ & -1.8978 \\
\hline & {$[1.851]$} & [4.431] & [1.050] & [.919] & [2.438] & [1.875] \\
\hline Observations & 412 & 677 & 412 & 677 & 412 & 677 \\
\hline$R^{2}$ & .724 & .699 & .557 & .718 & .748 & .695 \\
\hline
\end{tabular}

Note. Robust standard errors in brackets, clustered at the health facility level. AIDSeasy is defined as follows: $=2$ if the individual believes that AIDS is curable, $=1$ if individual believes that AIDS can be treated but is not curable, and $=0$ if he believes that AIDS is not treatable. Casual sex is any sexual intercourse with a nonregular partner, risky is defined as unprotected sex with a noncohabiting partner, and abstinence is defined over the last 12 .

$\star p<.10$.

$\star \star *<<.05$.

$\star \star \star ~ p<.01$.

Tables 6 and 7 revert to the specification in table 4 adding to the individual fixed effects interaction terms between household fixed effects and an indicator for the survey round. Table 6 focuses on family members of individuals living with HIV/AIDS. In that group, there is some suggestive evidence of disinhibition behaviors: AIDSeasy is positively associated with casual sex for men and women and with risky sex for women. Table 7 analyzes the behaviors of members of households living in the neighborhood of individuals living with HIV/AIDS. For that group as well, there is suggestive evidence of disinhibition behaviors: even though the positive association between AIDSeasy and risky sex is not statistically significant, the positive association between AIDSeasy and casual sex is significant for men and women.

Taken together, the results in tables 5-7 are suggestive that there might be disinhibition behaviors in the population (at least in our sample of household members of individuals living with HIV/AIDS and of comparison households living in their neighborhood), but that those behaviors are not found among people living with HIV/AIDS. We should, however, stress that our specifications, while they account for time-invariant unobserved characteristics and time-variant unobservables at the community or the household level, cannot account for time-variant unobserved individual characteristics. Our 
TABLE 6

THE ASSOCIATION BETWEEN PERCEPTIONS ABOUT AIDS AND SEXUAL BEHAVIORS AMONG FAMILY MEMBERS OF INDIVIDUAL LIVING WITH HIV/AIDS, CONTROLLING FOR INDIVIDUAL FIXED EFFECTS AND TIME-VARYING HOUSEHOLD LEVEL UNOBSERVABLES

\begin{tabular}{|c|c|c|c|c|c|c|}
\hline & \multicolumn{2}{|c|}{ Casual } & \multicolumn{2}{|c|}{ Risky } & \multicolumn{2}{|c|}{ Abstinence } \\
\hline & $\begin{array}{l}\text { Men } \\
(1)\end{array}$ & $\begin{array}{l}\text { Women } \\
\text { (2) }\end{array}$ & $\begin{array}{l}\text { Men } \\
\text { (3) }\end{array}$ & $\begin{array}{l}\text { Women } \\
\text { (4) }\end{array}$ & $\begin{array}{l}\text { Men } \\
(5)\end{array}$ & $\begin{array}{l}\text { Women } \\
(6)\end{array}$ \\
\hline \multirow[t]{2}{*}{ AIDSeasy } & $.1244^{\star \star \star}$ & $.0721^{\star}$ & .0376 & $.0972^{\star \star}$ & .0247 & -.0222 \\
\hline & {$[.037]$} & {$[.040]$} & {$[.035]$} & {$[.042]$} & {$[.054]$} & {$[.022]$} \\
\hline \multirow[t]{2}{*}{ Follow-up } & -.0093 & -.0251 & .0057 & -.0196 & $-.1024^{\star \star}$ & $.5299 * \star \star$ \\
\hline & {$[.063]$} & {$[.032]$} & [.019] & {$[.014]$} & {$[.038]$} & {$[.036]$} \\
\hline \multirow[t]{2}{*}{ age } & .0641 & .0932 & .0043 & .0058 & $.1172^{\star \star \star}$ & -.0774 \\
\hline & {$[.057]$} & {$[.067]$} & {$[.032]$} & {$[.038]$} & {$[.037]$} & [.103] \\
\hline \multirow[t]{2}{*}{ age2 } & -.0014 & -.0012 & -.0003 & .0002 & -.0004 & .0008 \\
\hline & {$[.001]$} & {$[.001]$} & [.001] & {$[.001]$} & {$[.001]$} & {$[.001]$} \\
\hline \multirow{2}{*}{ Constant } & -.2278 & -1.2473 & .1487 & -.2669 & $-2.7939 * \star \star *$ & 1.0411 \\
\hline & [1.646] & [1.219] & {$[.533]$} & [.455] & [.995] & {$[1.701]$} \\
\hline Observations & 1,086 & 1,084 & 1,086 & 1,084 & 1,086 & 1,084 \\
\hline$R^{2}$ & .819 & .804 & .660 & .686 & .690 & .643 \\
\hline
\end{tabular}

Note. Robust standard errors in brackets, clustered at the health facility level. AIDSeasy is defined as follows: $=2$ if the individual believes that AIDS is curable, $=1$ if individual believes that AIDS can be treated but is not curable, and $=0$ if he believes that AIDS is not treatable. Casual sex is any sexual intercourse with a nonregular partner, risky is defined as unprotected sex with a noncohabiting partner, and abstinence is defined over the last 12.

$\star p<.10$.

** $p<.05$.

$\star \star \star p<.01$.

TABLE 7

THE ASSOCIATION BETWEEN PERCEPTIONS ABOUT AIDS AND SEXUAL BEHAVIORS AMONG MEMBERS OF NEIGHBORING HOUSEHOLDS, CONTROLLING FOR INDIVIDUAL FIXED EFFECTS AND TIME-VARYING HOUSEHOLD LEVEL UNOBSERVABLES

\begin{tabular}{|c|c|c|c|c|c|c|}
\hline & \multicolumn{2}{|c|}{ Casual } & \multicolumn{2}{|c|}{ Risky } & \multicolumn{2}{|c|}{ Abstinence } \\
\hline & $\begin{array}{l}\text { Men } \\
(1)\end{array}$ & $\begin{array}{l}\text { Women } \\
\text { (2) }\end{array}$ & $\begin{array}{l}\text { Men } \\
\text { (3) }\end{array}$ & $\begin{array}{l}\text { Women } \\
\text { (4) }\end{array}$ & $\begin{array}{l}\text { Men } \\
(5)\end{array}$ & $\begin{array}{c}\text { Women } \\
\text { (6) }\end{array}$ \\
\hline \multirow[t]{2}{*}{ AIDSeasy } & $.1676^{\star \star \star}$ & $.0881^{* *}$ & .0186 & .0600 & -.0612 & .0160 \\
\hline & {$[.053]$} & {$[.035]$} & [.035] & {$[.040]$} & [.063] & {$[.054]$} \\
\hline \multirow[t]{2}{*}{ Follow-up } & $-1.0403^{\star \star \star}$ & $-.1559 \star \star *$ & .0055 & -.0565 & $.0221 \star \star$ & .0017 \\
\hline & {$[.024]$} & {$[.062]$} & {$[.015]$} & {$[.046]$} & {$[.010]$} & [.059] \\
\hline \multirow[t]{2}{*}{ age } & .0533 & .1154 & -.0321 & .0323 & $-.1176^{\star \star \star}$ & .0012 \\
\hline & {$[.081]$} & {$[.101]$} & {$[.067]$} & {$[.066]$} & {$[.034]$} & [.094] \\
\hline \multirow[t]{2}{*}{ age2 } & -.0002 & -.0010 & .0005 & -.0007 & $.0016^{\star \star \star}$ & -.0004 \\
\hline & {$[.001]$} & {$[.001]$} & {$[.001]$} & [.001] & {$[.000]$} & [.002] \\
\hline \multirow[t]{2}{*}{ Constant } & -.0565 & -2.0083 & .5699 & -.1528 & $1.9829 * \star \star$ & .4674 \\
\hline & [1.378] & [1.913] & [1.087] & [1.134] & {$[.622]$} & [1.492] \\
\hline Observations & 852 & 902 & 852 & 902 & 852 & 902 \\
\hline$R^{2}$ & .836 & .855 & .676 & .668 & .727 & .729 \\
\hline
\end{tabular}

Note. Robust standard errors in brackets, clustered at the health facility level. AIDSeasy is defined as follows: $=2$ if the individual believes that AIDS is curable, $=1$ if individual believes that AIDS can be treated but is not curable, and $=0$ if he believes that AIDS is not treatable. Casual sex is any sexual intercourse with a nonregular partner, risky is defined as unprotected sex with a noncohabiting partner, and abstinence is defined over the last 12 .

* $p<.10$.

** $p<.05$.

$\star \star \star ~ p<.01$. 
results should therefore be interpreted with this potential source of endogeneity in mind.

Tables A1-A6 in the appendix reproduce the same specifications as in tables 2-7, but instead of using AIDSeasy as the independent variable of interest, we have entered "AIDS can be cured" and "AIDS can be treated" as separate independent variables, for robustness. For lack of space, we cannot describe the results of those tables in detail, but overall the results are similar and go in the same direction. In the overall sample, there is evidence of disinhibition when only individual fixed effects (appendix table A1) and individual fixed effects with interaction terms between health facility indicators and time indicators (appendix table A2) are entered. When interaction terms between household fixed effects and time indicators are entered (appendix table A3), only a few of the positive association between the AIDS treatment perceived efficacy variable and the sexual behaviors variable persist. But in the analysis by subsample (appendix tables A4-A6), the same pattern emerges as in tables 5-7: no evidence of disinhibition behaviors for individuals living with HIV/AIDS, but several coefficients suggestive of disinhibition behaviors for family members of individuals living with HIV/AIDS (appendix table A5) and in comparison households (appendix table A6).

Descriptive statistics in table 1 and figure 4 suggest that the decline in the AIDSeasy variable between the two survey rounds is associated with the population's accumulation of treatment experience, as measured by the variable cumestpts. Appendix table A7 presents individual fixed effect regression estimates of the impact of cumestpts on the variable AIDSeasy. The estimated association between the logarithm of cumespts and the variable AIDSeasy is negative in every subset of the population and is statistically significant at the $1 \%$ level in the pooled samples for men and women and for men alone.

While supporting the narrative that experience with AIDS treatment can decrease a population's confidence in the efficacy of ART, the results in appendix table A7 also show that, with the possible exception of the samples of pooled men and women and pooled men, the logarithm of cumestpts explains too little of the variation in AIDSeasy to serve as its instrument in a secondstage instrumental variables regression. ${ }^{14}$

\section{Conclusion}

We use data from Mozambique to test for disinhibition behaviors resulting from increased access to ART. The main hypothesis is that people may alter

14 The variable cumestpts is measured at the health facility and could change from the first round of the survey to the next one. Hence this variable is absorbed by the health facility $\times$ time interaction terms or the household $\times$ time interactions terms. 
their sexual behaviors in response to a perceived decrease in the opportunity costs of contracting AIDS that results from expected access to efficacious ART. Such compensating behaviors, if large enough, could potentially increase HIV transmission, thus offsetting some of the positive effects of increased access to ART. After controlling for individual fixed effects, time-varying health facility and time-varying household unobserved, we find a strong positive association between the perception that ART is efficacious and risky sexual behaviors. Such an association is suggestive of disinhibition behaviors, consistent with prior literature on risk taking in the United States and Europe, following the introduction of ART.

The association between ART perceived efficacy and risky sexual behaviors is the strongest for respondents from comparison households and for family members of persons living with HIV/AIDS. One could speculate that increased access to ART might lead to increased risky sexual behaviors for the general population but not for HIV positive persons. If this were confirmed, then ART programs may need to be supplemented with behavioral prevention programs that target the general population. Absent such supporting prevention programs, increased risky sexual behaviors could offset some of the benefits from increased access to treatment.

Our finding of a positive association between confidence that ART works and risk behavior comes from a Mozambican context in which confidence in ART declined between the two rounds of our survey. Thus, our findings suggest that people's disillusionment with ART between 2007 and 2008 led in many cases to increased inhibition of their sexual behavior.

To sum up, our results suggest that scaling up access to ART without behavioral prevention programs may not be optimal if the objective is to contain the disease, since people would adjust their sexual behavior in response to the perceived changes in risk. Therefore, prevention programs need to include educational messages about the limitations as well as the health benefits of ART, and they need to address the changing beliefs about HIV in the era of increasing ART availability. Finally, prevention messages must accommodate the gender difference in disinhibition behaviors. 


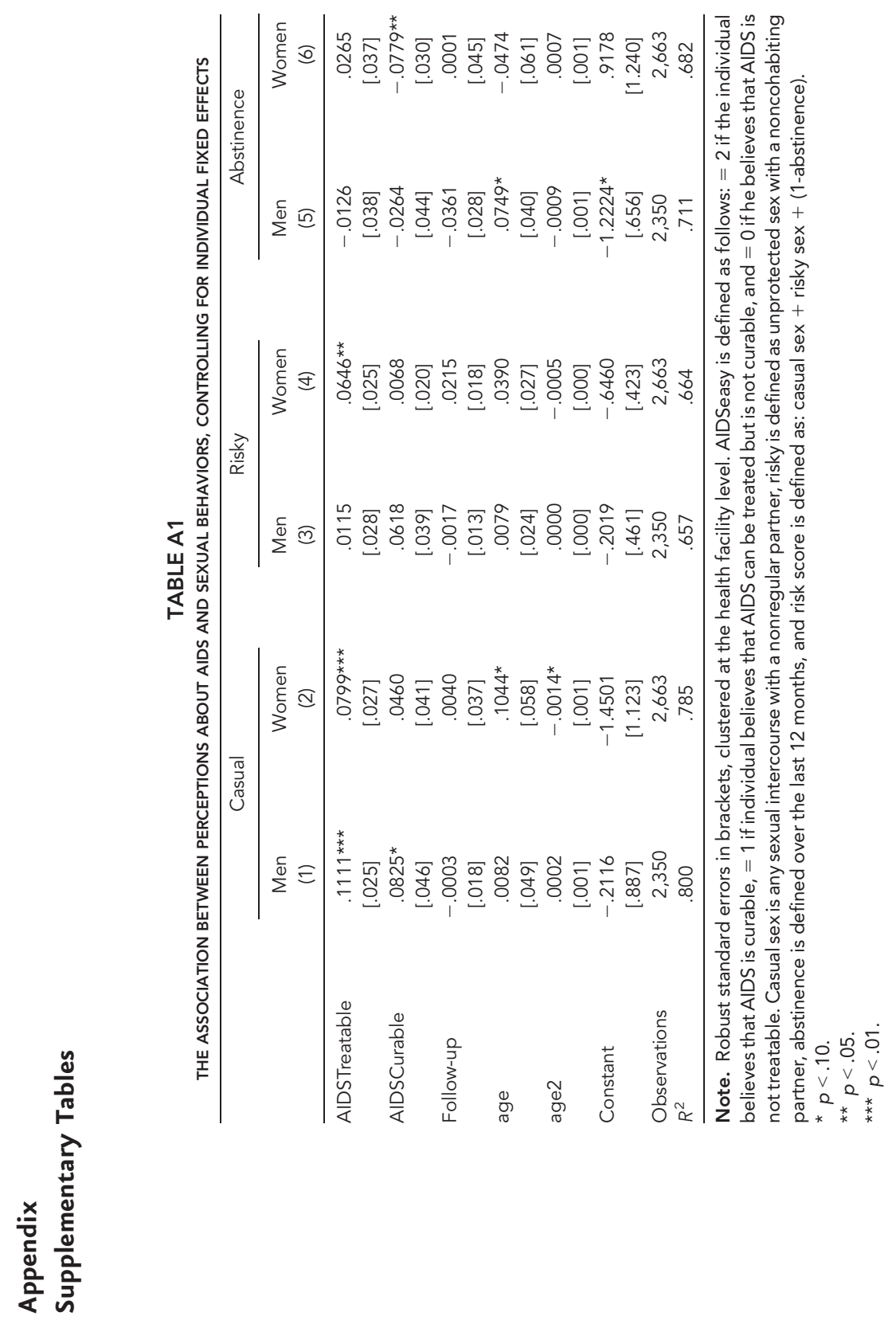




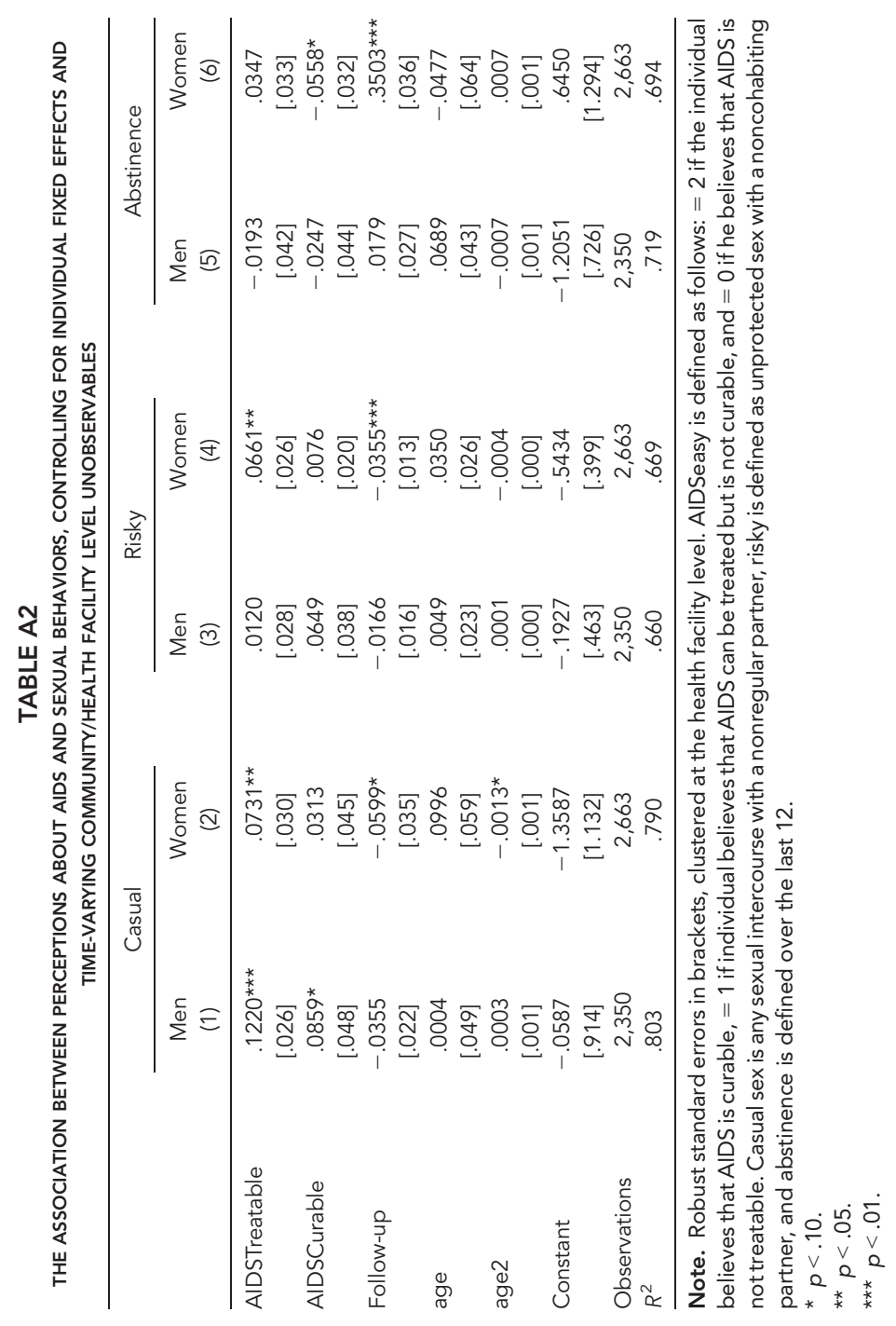




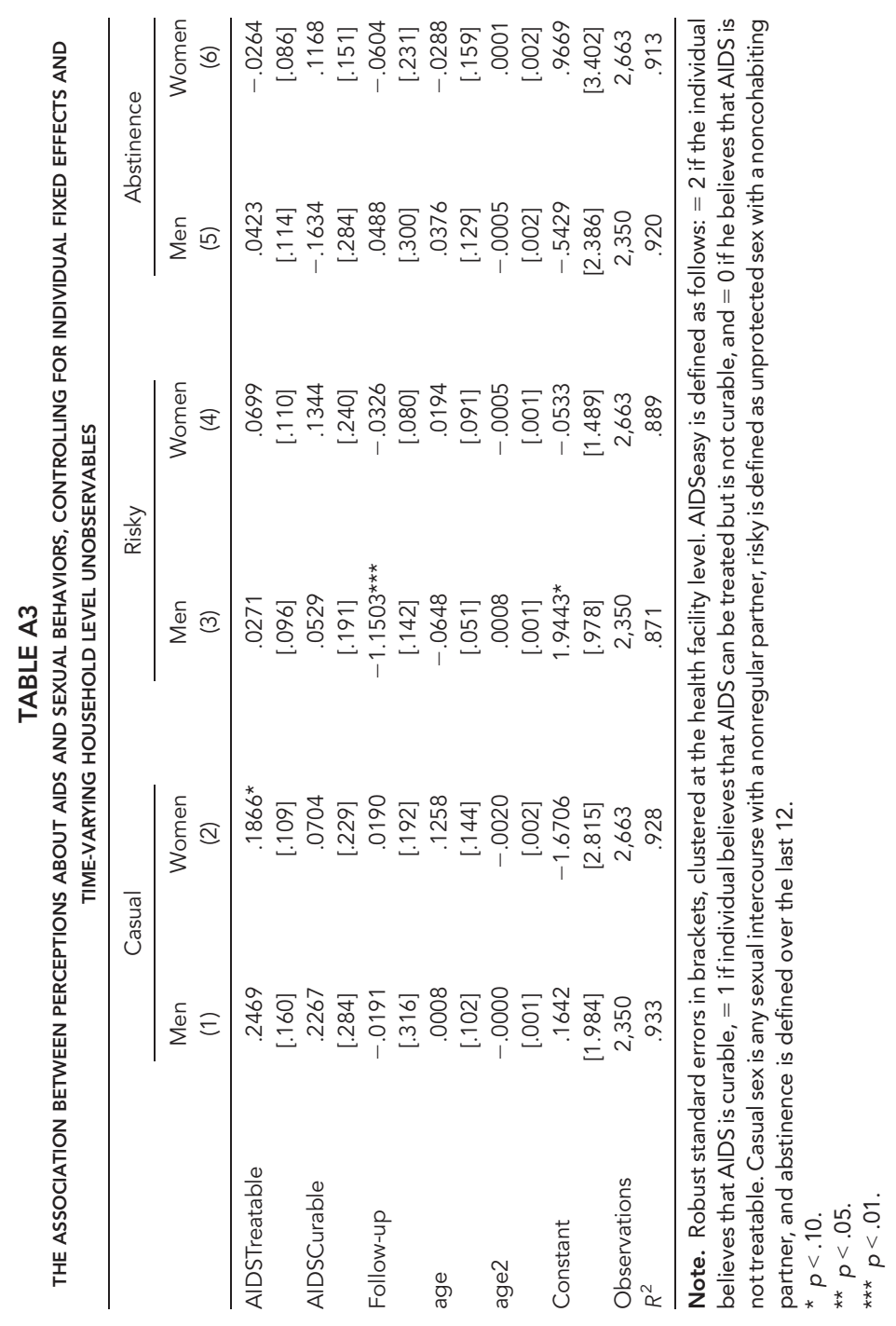




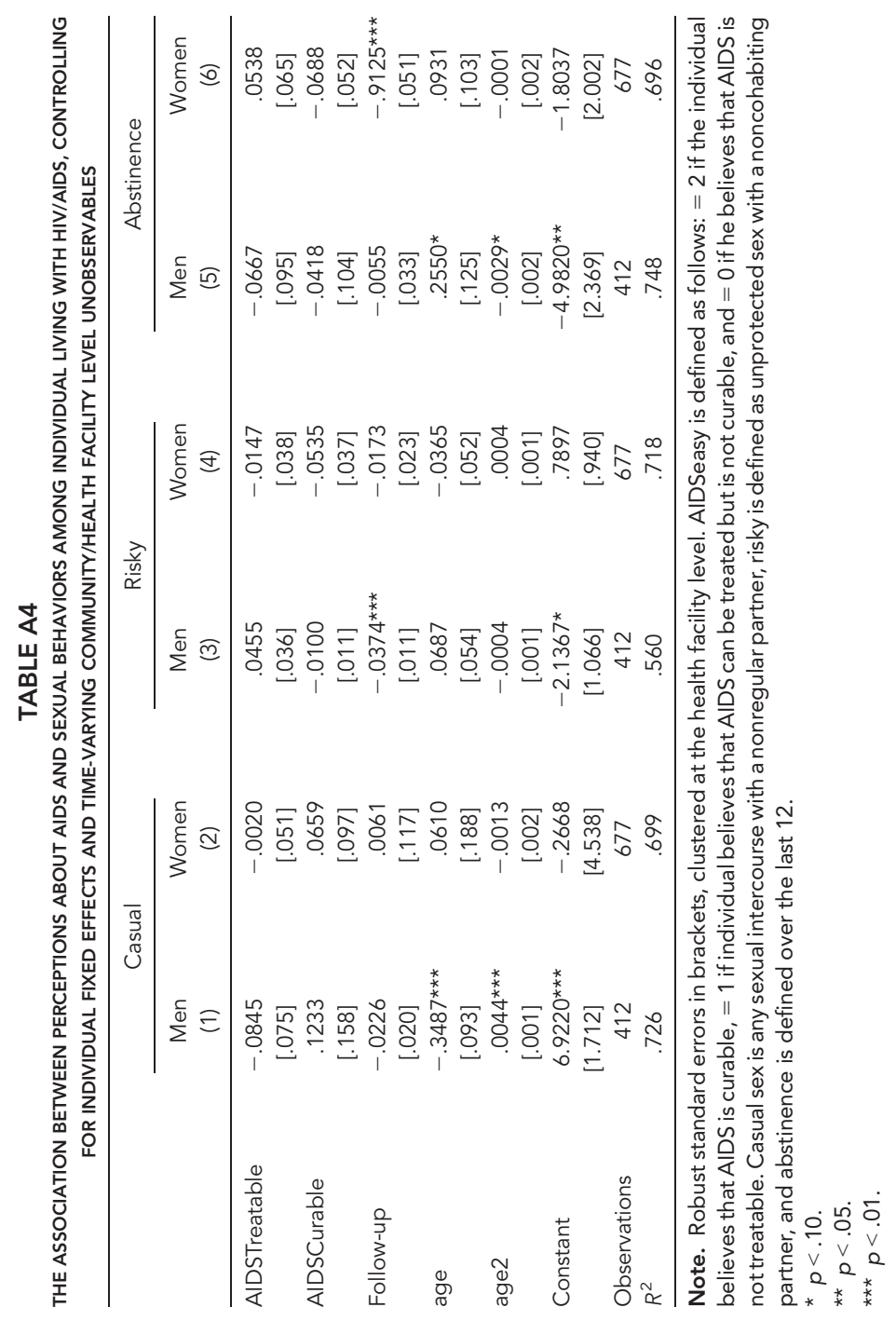




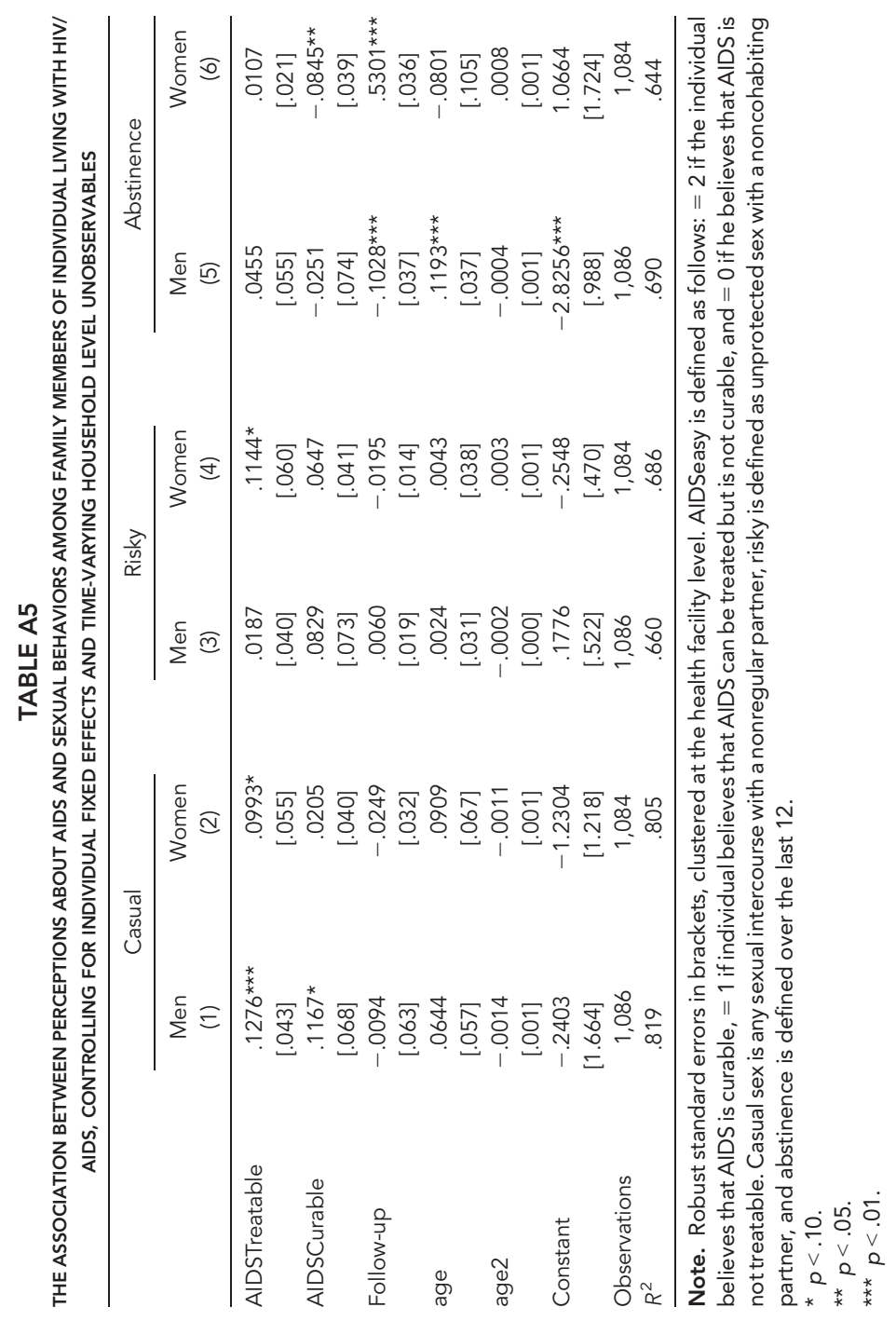




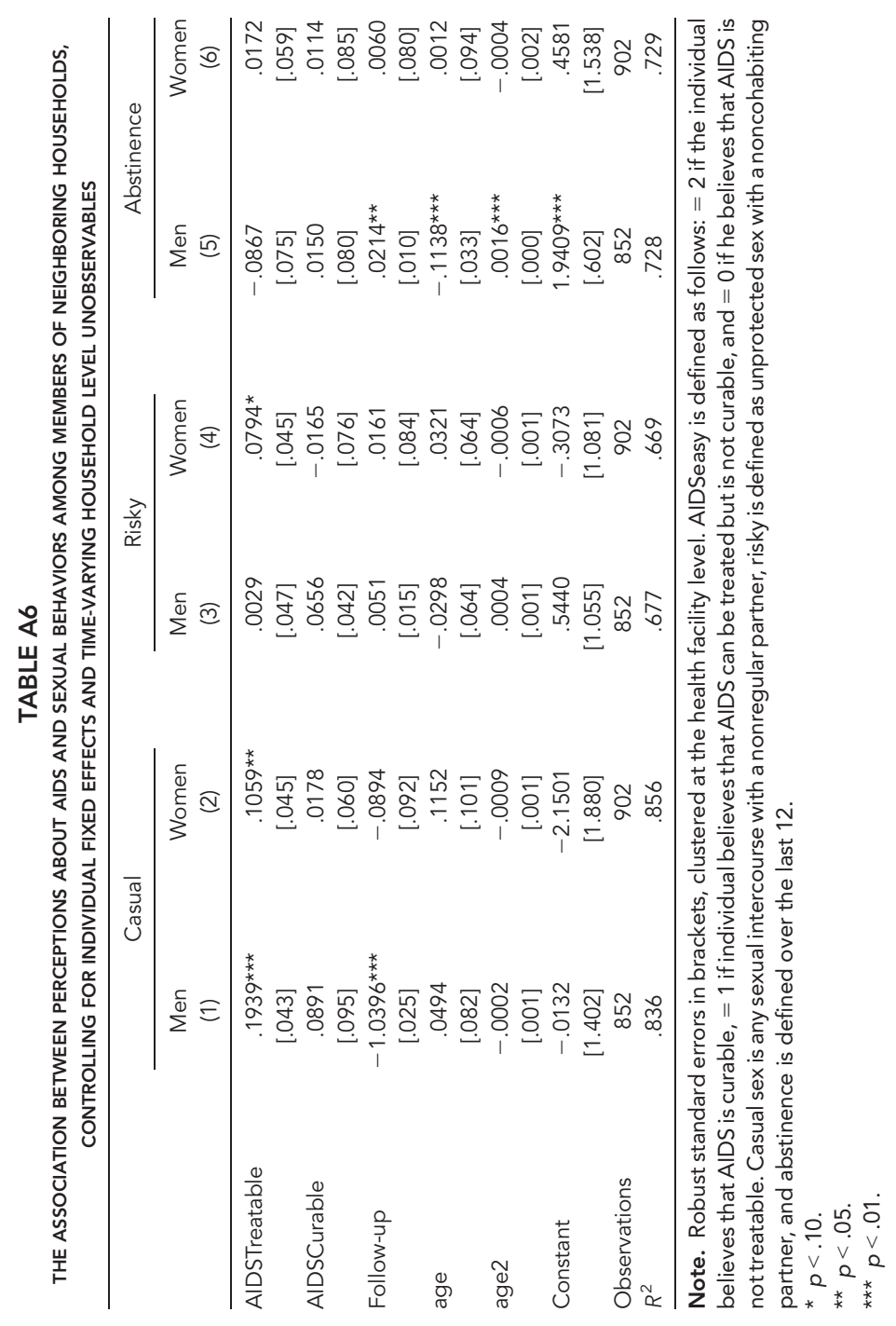


TABLE A7

THE ASSOCIATION BETWEEN CUMULATED LOCAL EXPERIENCE WITH ART (CUMESTPTS) AND THE PERCEPTION THAT ART IS EFFICACIOUS (AIDSEASY), CONTROLLING FOR INDIVIDUAL FIXED EFFECTS

\begin{tabular}{|c|c|c|c|c|c|c|c|c|}
\hline & \multicolumn{4}{|c|}{ Men } & \multicolumn{4}{|c|}{ Women } \\
\hline & Pooled & $\mathrm{HIV}+$ & Family & Comp. hh & Pooled & $\mathrm{HIV}+$ & Family & Comp. hh \\
\hline Follow-up & $\begin{array}{l}.022 \\
(.043)\end{array}$ & $\begin{array}{l}.019 \\
(.073)\end{array}$ & $\begin{array}{c}.068 \\
(.113)\end{array}$ & $\begin{array}{r}-.007 \\
(.074)\end{array}$ & $\begin{array}{c}-.124^{\star \star} \\
(.049)\end{array}$ & $\begin{array}{r}-.089 \\
(.114)\end{array}$ & $\begin{array}{r}-.134^{\star} \\
(.076)\end{array}$ & $\begin{array}{l}-.127 \\
(.104)\end{array}$ \\
\hline age & $\begin{array}{l}.034 \\
(.067)\end{array}$ & $\begin{array}{l}.118 \\
(.125)\end{array}$ & $\begin{array}{l}.051 \\
(.128)\end{array}$ & $\begin{array}{c}-.011 \\
(.138)\end{array}$ & $\begin{array}{c}.072 \\
(.073)\end{array}$ & $\begin{array}{l}.106 \\
(.199)\end{array}$ & $\begin{array}{l}.119 \\
(.106)\end{array}$ & $\begin{array}{l}.035 \\
(.165)\end{array}$ \\
\hline agê2 & $\begin{array}{c}-.001 \\
(.001)\end{array}$ & $\begin{array}{c}-.002 \\
(.002)\end{array}$ & $\begin{array}{c}-.001 \\
(.002)\end{array}$ & $\begin{array}{l}.000 \\
(.002)\end{array}$ & $\begin{array}{c}-.001 \\
(.001)\end{array}$ & $\begin{array}{r}-.002 \\
(.003)\end{array}$ & $\begin{array}{c}-.002 \\
(.002)\end{array}$ & $\begin{array}{l}.001 \\
(.002)\end{array}$ \\
\hline In(cumestpts) & $\begin{array}{c}-.074^{\star \star \star} \\
(.027)\end{array}$ & $\begin{array}{r}-.030 \\
(.048)\end{array}$ & $\begin{array}{r}-.073 \\
(.048)\end{array}$ & $\begin{array}{c}-.092^{\star \star} \\
(.043)\end{array}$ & $\begin{array}{r}-.033 \\
(.028)\end{array}$ & $\begin{array}{r}-.040 \\
(.047)\end{array}$ & $\begin{array}{r}-.044 \\
(.052)\end{array}$ & $\begin{array}{r}-.030 \\
(.045)\end{array}$ \\
\hline$N$ & 1,444 & 296 & 662 & 486 & 1,718 & 490 & 712 & 516 \\
\hline
\end{tabular}

Note. The dependent variable, AIDSeasy, is defined as follows: $=2$ if the individual believes that AIDS is curable, $=1$ if individual believes that AIDS can be treated but is not curable, and $=0$ if he believes that AIDS is not treatable. Casual sex is any sexual intercourse with a nonregular partner, risky is defined as unprotected sex with a noncohabiting partner, and abstinence is defined over the last 12 months. The sample size is smaller than that from the rest of the tables because cumestpts is estimated from a separate health facility level survey, and some observations from the household survey did not match with the health facility level survey. These observations are dropped from the estimations shown in this table. Comp. $\mathrm{hh}=$ comparison households.

$\star p<.10$.

$\star \star x<.05$.

$\star \star \star ~ p<.01$.

\section{References}

ACTAfrica and Global HIV Program. 2007. “Treatment Acceleration Program: Learning from the Experience Gained and the Challenges Ahead.” Photocopy, World Bank, Washington, DC.

Ahituv, A., V. J. Hotz, and T. Philipson. 1996. "The Responsiveness of the Demand for Condoms to the Local Prevalence of AIDS." Iournal of Human Resources 31, no. 4:869-97.

Arndt, C. 2006. "HIV/AIDS, Human Capital, and Economic Growth Prospects for Mozambique." Lournal of Policy Modeling 28, no. 5:477-89.

Clark L. R., C. Brasseux, D. Richmon, P. Getson, and L. J. D’Angelo. 1998. "Effect of HIV Counseling and Testing on Sexually Transmitted Diseases and Condom Use in an Urban Adolescent Population." Archives of Pediatrics and Adolescent Medicine 152, no. 3:269-73.

Cohen, A., and L. Einav. 2003. "The Effects of Mandatory Seat Belt Laws on Driving Behavior and Traffic Fatalities." Review of Economics and Statistics 85, no. 4:828-43.

Cohen, C. R., M. Montandon, A. W. Carrico, S. Shiboski, A. Bostrom, A. Obure, Z. Kwena, R. C. Bailey, R. Nguti, and E. A. Bukusi. 2009. "Association of Attitudes and Beliefs towards Antiretroviral Therapy with HIV-Seroprevalence in the General Population of Kisumu, Kenya.” PLoS ONE 4, no. 3, e4573. Electronically published March 2009.

Cohen, M. S., Y. Q. Chen, M. McCauley, et al. 2011. "Prevention of HIV-1 Infection with Early Antiretroviral Therapy." New Enoland Iournal of Medicine 365, no. 6:493-505. 
Dukers, N., J. Goudsmit, J. de Wit, M. Prins, G. Weyerling, and R. Coutinho. 2001. "Sexual Risk Behaviour Relates to the Virological and Immunological Improvements during Highly Active Antiretroviral Therapy in HIV-1 Infection.” AIDS 15, no. 3:369-78.

Eaton, L., and S. Kalichman. 2007. "Risk Compensation in HIV Prevention: Implications for Vaccines, Microbicides, and Other Biomedical HIV Prevention Technologies." Current HIVIAIDS Reports 4, no. 4:165-72.

Gertler, P., M. Shah, and S. Bertozzi. 2005. "Risky Business: The Market for Unprotected Commercial Sex.” Lournal of Political Economy 113, no. 3:518-50.

Green, E. C., and A. H. Ruark. 2011. AIDS, Behavior, and Culture: Understanding Evidence-Based Prevention. Walnut Creek, CA: Left Coast Press.

Gremy, I., and N. Beltzer. 2004. "HIV Risk and Condom Use in the Adult Heterosexual Population in France between 1992 and 2001: Return to the Starting Point?" AIDS 18, no. 5:805-9.

Hammer, S., M. Saag, M. Schechter, J. Montaner, R. Schooley, D. Jacobsen, M. Thompson, C. Carpenter, M. Fischl, B. Gazzard, et al. 2006. "Treatment for Adult HIV Infection: 2006 Recommendations of the International AIDS SocietyUSA Panel." Iournal of the American Medical Association 296, no. 7:827-43.

Jha, P., L. Vaz, F. Plummer, N. Nagelkerke, B. Willbond, E. Ngugi, S. Moses, G. John, R. Nduati, K. MacDonald, et al. 2001. "The Evidence Base for Interventions to Prevent HIV Infection in Low and Middle-Income Countries.” Working Paper Series WG 5, Commission on Macroeconomics and Health, Geneva.

Kabiru, C., N. Luke, C. Izugbara, and E. Zulu. 2010. "The Correlates of HIV Testing and Impacts on Sexual Behavior: Evidence from a Life History Study of Young People in Kisumu, Kenya." BMC Public Health 10:412-23.

Kalichman, S. 1998. "Post-Exposure Prophylaxis for HIV Infection in Gay and Bisexual Men: Implications for the Future of HIV Prevention." American Iournal of Preventive Medicine 15, no. 2:120-27.

Kazianga, H., and C. Udry. 2006. "Consumption Smoothing? Livestock, Insurance and Drought in Rural Burkina Faso." Iournal of Development Economics 79, no. 2:413-46.

Lakdawalla, D., N. Sood, and D. Goldman. 2006. "HIV Breakthroughs and Risky Sexual Behavior." Ouarterlv Iournal of Economics 121, no. 3:1063-1102.

Lave, L. B., and W. E. Weber. 1970. "A Benefit-Cost Analysis of Auto Safety Features." Applied Economics 2, no. 4:265-75.

Marseille, E., P. Hofmann, and J. Kahn. 2002. "HIV Prevention before HAART in Sub-Saharan Africa." Lancet 359, no. 9320:1851-56.

McCarthy, P., and W. K. Talley. 1999. "Evidence on Risk Compensation and Safety Behavior." Economics Letters 62, no. 1:91-96.

Mechoulan, S. 2007. "Risky Sexual Behavior, Testing, and HIV Treatments." Forum for Health Economics and Policy 10, no. 2. http://works.bepress.com/stephane _mechoulan/6.

Mozambican Ministry of Health. 2009. National TARV Data. Maputo, Mozambique: Government of Mozambique. 
Over, M., E. Marseille, K. Sudhakar, J. Gold, I. Gupta, A. Indrayan, S. Hira, N. Nagelkerke, A. Rao, and P. Heywood. 2006. "Antiretroviral Therapy and HIV Prevention in India: Modeling Costs and Consequences of Policy Options." Sexually Transmitted Diseases 33, no. 10:S145-S152.

Over, M., A. Revenga, E. Masaki, W. Peerapatanapokin, J. Gold, V. Tangcharoensathien, and S. Thanprasertsuk. 2007. "The Economics of Effective AIDS Treatment in Thailand." AIDS 21:S105-S116.

Oza, A. 2009. "Plan B as Insurance: The Effect of Over-the-Counter Emergency Contraception on Pregnancy Termination and STIs." Unpublished manuscript, University of Chicago.

Peltzman, S. 1975. "The Effects of Automobile Safety Regulation.” Iournal of Political Economy 83, no. 4:677-726.

Rao, V., I. Gupta, M. Lokshin, and S. Jana. 2003. "Sex Workers and the Cost of Safe Sex: The Compensating Differential for Condom Use among Calcutta Prostitutes." Iournal of Development Economics 71, no. 2:585-603.

Schultz, T. 2004. "Health Economics and Applications in Developing Countries." Iournal of Health Economics 23, no. 4:637-41.

Singh, S., J. Darroch, and A. Bankole. 2004. "A, B and C in Uganda: The Roles of Abstinence, Monogamy and Condom Use in HIV Decline." Reproductive Health Matters 12, no. 23:129-35.

UNGASS. 2010. "Mozambique Progress Report, 2008-2009.” Report, United Nations General Assembly Special Session on HIV and AIDS-Conselho Nacional de Combate ao SIDA, Mozambique.

Wang, C., S. E. Hawes, A. Gaye, P. S. Sow, I. Ndoye, L. E. Manhart, A. Wald, C. W. Critchlow, and N. B. Kiviat. 2007. "HIV Prevalence, Previous HIV Testing, and Condom Use with Clients and Regular Partners among Senegalese Commercial Sex Workers." Sexually Transmitted Infections 83:534-40. 